\title{
Investigation of antioxidant capacity of peptide fractions from the Tra catfish by-product-derived proteolysate using Flavourzyme ${ }^{\circledR} 500 \mathrm{mg}$
}

\author{
Tam Dinh-Le Vo, Cuong Vi Tran
}

\begin{abstract}
In this study, the antioxidant potential of peptide fractions isolated from the Tra catfish (Pangasius hypophthalmus) by-product-derived hydrolysate using ultrafiltration centrifugal devices with 3 distinct molecular-weight cutoffs (MWCOs) of $5 \mathrm{KDa}, 10 \mathrm{KDa}$, and 30KDa was investigated. Firstly, the chemical composition of the Tra catfish byproducts was analyzed. The result showed that the Tra catfish by-products contained $\mathbf{5 8 . 5 \%}$ moisture, 33.9\% crude protein, $\mathbf{5 0 . 1 \%}$ crude lipid and $\mathbf{1 5 . 8 \%}$ ash (on dry weight basis). Secondly, the effects of enzyme content, hydrolysis time on the antioxidant activity of the hydrolysate were studied using DPPH• (2,2-diphenyl-1-picrylhydrazyl) radical scavenging method (DPPH• SM), and FRAP (ferric reducing antioxidant potential) method. Flavourzyme ${ }^{\circledR} 500$ MG was used for hydrolysis. The result revealed that the antioxidant activity of the proteolysate reached the peak when the hydrolysis time was $3 \mathrm{~h}$, enzyme/substrate $(\mathrm{E} / \mathrm{S})$ ratio was $25 \mathrm{U} / \mathrm{g}$ protein, hydrolysis temperature was $500 \mathrm{C}$, $\mathrm{pH}$ was 7 , and the degree of hydrolysis $(\mathrm{DH})$ of the hydrolysate reached 37.4\%. Next, the proteolysate was further fractionated using MWCOs of 5KDa, 10KDa, and $30 \mathrm{KDa}$ and the peptide fractions were investigated for their antioxidant activity. The result showed that the <5KDa fraction showed strongest antioxidant activity with the $50 \%$ DPPH - inhibition concentration (IC50) of $3079.34 \pm 75.29 \mu \mathrm{g} / \mathrm{mL}$ and FRAP value of $611.28 \pm 4.5 \mu \mathrm{M}$ Trolox equivalent.
\end{abstract}

Manuscript Received on December 06th, 2016, Manuscript Revised February 17th, 2017.

This research is funded by Ho Chi Minh City University of Technology-VNU-HCM, under grant number T-KTHH-201637.

Tam Dinh-Le Vo, Cuong Vi Tran - Faculty of Chemical Engineering, Ho Chi Minh City Univeristy of Technology Viet Nam National University Ho Chi Minh City.
The second strongest fraction was 5-10KDa with the IC50 and FRAPS value of $4709.3 \pm 222.22 \mu \mathrm{g} / \mathrm{mL}$ and 323.62 $\pm 2.54 \mu \mathrm{M}$ Trolox equivalent, respectively. The 10-30KDa fraction showed weakest antioxidant capacity with the IC50 of $5847.73 \pm 128.68 \mu \mathrm{g} / \mathrm{mL}$ and FRAP value of $291.4 \pm 2.65 \mu \mathrm{M}$ Trolox equivalent. The antioxidant peptides derived from Tra catfish by-products proteolysate have the potential to be used as natural antioxidant ingredients in pharmaceutical and food industry.

Index Terms - antioxidant activity, antioxidant peptide, hydrolysate, Tra catfish by-products.

\section{INTRODUCTION}

I $\mathrm{n}$ Vietnam, the farming and processing of Tra catfish in the Mekong Delta has developed very quickly. Fillet is the main product of catfish processing industry with approximately $65-70 \%$ of by-products including skin, bone, head, fat and viscera. These by-products are very important bioresources that might be utilized for applications in food, health care products, and pharmaceuticals [1]. In Vietnam, they have been used as raw materials for production of fish meal for livestock, biodiesel, gelatin, and fish oil extraction.

Recently, enzymatic protein hydolysates from fish processing by-products have been shown to have antioxidant activity. The antioxidant capacity of proteolysate was described through IC50. The 1018.48Da antioxidant peptide was identified from the peptic hydrolysate of salmon pectoral fin protein with the IC50 value against DPPH of 486 $\mu \mathrm{M}[2]$. The 1519Da antioxidant peptide identified from peptic hydrolysate of tuna backbone protein significantly quenched DPPH free radical [3]. The 
around $3.5 \mathrm{KDa}$ from sardinelle viscera protein hydrolysate was found to exhibit the highest DPPH radical-scavenging activity [4]. Flavourzyme has been shown to be a good enzyme preparation to obtain proteolysate with high antioxidant potential [5]. However, no information has been reported on the antioxidant activity of Tra catfish by-productderived proteolysate using Flavourzyme for application of a natural antioxidant ingredient.

The main objective of the study was to investigate the antioxidant activity of the MWCOfractionated peptide fractions from Flavourzyme hydrolysate of Tra catfish by-products using $\mathrm{DPPH} \cdot \mathrm{SM}$ and FRAP method, with the aim of using this fish by-product source to produce natural antioxidant ingredients.

\section{MATERIALS AND METHODS.}

\subsection{Materials}

Tra catfish by-products

The Tra catfish frames included heads, bones, fins, tails and some remaining flesh attached to the frames were provided by a local catfish processing plant in Tien Giang province, Vietnam. The byproducts were transported on ice to the Biochemical laboratory of Ho Chi Minh City University of Technology within 4 hours, individually packed in polyethylene bags, labeled and stored $-80{ }^{\circ} \mathrm{C}$ until used.

\section{Enzyme source and chemicals}

Commercial Flavourzyme 500 MG from Aspergillus oryzae was obtained from Novozymes with the declared activity of $500 \mathrm{LAPU} / \mathrm{g}$. The optimal temperature and $\mathrm{pH}$ of the enzyme were 40-60 ${ }^{\circ} \mathrm{C}$ and 5-7, respectively.

Chemicals were purchased from Sigma-Aldrich and Merck. All reagents were of analytical grade. Double-distilled water was used in experiments.

\subsection{Methods}

Determination of chemical composition of the by-products

The contents of moisture, crude protein, crude fat and ash were determined based on the methods of AOAC (2000) [6]. The total crude protein content was determined using Kjeldahl method with Nitrogen conversion factor of 6.25 .

Preparation of Tra catfish by-product hydrolysates
Procedure of Bhaskar et al. (2007) [7] with slight modification was applied to prepare the hydrolysate. For each batch, water was added with the ratio of water: by-product of $1: 1(\mathrm{w} / \mathrm{v})$. The $\mathrm{pH}$ value of the mixture was adjusted to 7.0 before adding the enzyme for hydrolysis. Flavourzyme was added on the basis of standardized activity units which were determined using the method of Anson with slight modification [8]. Every 15 minutes, the $\mathrm{pH}$ value was adjusted using sodium hydroxide or hydrochloric acid solution of $0.1 \mathrm{~N}$. The reaction was terminated by heating the hydrolysates for $10 \mathrm{~min}$ at $90{ }^{\circ} \mathrm{C}$ in order to deactivate the Flavourzyme. The final hydrolysates were further centrifuged at $8,000 \mathrm{x}$ g for $10 \mathrm{~min}$ to remove insoluble substances and the obtained supernatants were freeze-dried using freeze-dryer (Alpha 1-2/Ld plus, UK). Samples were stored as hydrolyzed protein powder at $-80^{\circ} \mathrm{C}$ until used.

\section{Evaluation of protein content of hydrolysates}

The method of Lowry [9] was applied, using bovine serum albumin as a standard, to determine the protein contents of the hydrolysate.

Determination of degree of hydrolysis $(\mathrm{DH})$ of hydrolysate

Nitrogen solubility index was used to determine the DH of hydrolysate using trichloroacetic (TCA) acid as precipitating agent [10]. Kjeldahl method was used to determine nitrogen content.

Effects of proteolysis time, E/S ratio on the antioxidant activity of proteolysate

Experiments in effects of proteolysis time, E/S ratio on the antioxidant activity of proteolysate were performed as follows: Concerning the effect of proteolysis time, the Tra catfish by-products were hydrolyzed at $\mathrm{pH} 7,50^{\circ} \mathrm{C}, \mathrm{E} / \mathrm{S}$ ratio of 25 $\mathrm{U} / \mathrm{g}$ protein and the hydrolysis time was controlled from 1 to $5 \mathrm{~h}$. Regarding the effect of $\mathrm{E} / \mathrm{S}$ ratio, the by-products were hydrolyzed for $3 \mathrm{~h}, \mathrm{pH} 7,50^{\circ} \mathrm{C}$ and the $\mathrm{E} / \mathrm{S}$ ratio was controlled from 10 to $40 \mathrm{U} / \mathrm{g}$ protein.

Determination of antioxidant activity $\mathrm{DPPH} \bullet$ radical-scavenging capacity

The DPPH radical scavenging activity was assayed employing the method of Chen et al. (1998) [11] with slight modification. The mixture 
of sample and DPPH was incubated in the dark at room temperature for $30 \mathrm{~min}$. The absorbance at $517 \mathrm{~nm}$ was determined by a spectrophotometer.

Ferric Reducing Antioxidant Potential (FRAP) assay

The ferric reducing capacity of the hydrolysate was determined using a modified method of Benzie and Strain (1996) [12]. The reduction is monitored by measuring the change of absorbance at $593 \mathrm{~nm}$.

MWCO fractionation of the Tra catfish byproduct proteolysate

The proteolysate was further fractionated using MWCOs of $30 \mathrm{KDa}, 10 \mathrm{KDa}$, and $5 \mathrm{KDa}$ (ThermoFisher Scientific, USA; GE Healthcare Life Sciences, UK). Three peptide fractions of 10$30 \mathrm{KDa}, 5-10 \mathrm{KDa}$, and $<5 \mathrm{KDa}$ were collected and tested for their antioxidant capacity.

\section{Statistical analysis}

Data were presented as means \pm standard deviations of triplicate determinations. Mean differences among the measurements were statistically significant at the $95 \%$ confidence level. Analysis of variance (ANOVA) was performed using the Statgraphics Plus software (version 7.0).

\section{RESULTS AND DISCUSSION.}

\subsection{Composition analysis of Tra catfish by- products}

Proximate composition analyses of Tra catfish frame in this study revealed that it contained $58.5 \%$ moisture, $33.9 \%$ crude protein, $50.1 \%$ crude lipid and $15.8 \%$ ash (on dry weight basis). The protein content was higher than that of silver catfish (Pangasius sp.) frame (without head) which was $25 \%$ crude protein reported in the research of Amiza et al. [13]. This supposed that Tra catfish by-product can be used as a protein source for isolation of proteolysate or peptides.

\subsection{Effect of proteolysis time on antioxidant activity of protein hydrolysate}

The results of the effect of hydrolysis time on the antioxidant activity of protein hydrolysate derived from Tra catfish by-products using DPPH・ SM, and FRAP method were shown in Fig. 1. DPPH• scavenging activity and FRAP values of the protein hydrolysates generally increased as the hydrolysis time increased $(\mathrm{P}<0.05)$. The increase in proteolysis time led to the decrease in size of peptides; as a result, more and more smaller peptides were produced led to higher antioxidant activities of hydrolysate. This was in line with the previous report suggesting the increase of $\mathrm{DPPH} \cdot$ radical scavenging capacity and FRAP value due to the extension of hydrolysis time [14].

The antioxidant activity of protein hydrolysate depends on its amino acid composition and sequence. Hydrolysates rich in peptides containing hydrophobic amino acids, such as Pro, Leu, Ala, Trp and Phe enhance their antioxidant activity by increasing the solubility of peptides in lipid phase [15]. Tyr, Met, His and Lys were also known to possess antioxidant activity. Tryp, Tyr and His contains the indolic, phenolic, and imidazole groups, respectively, which serve as hydrogen donors. In addition, His and Tyr can make reactive oxygen species stable through electron/proton transfer. Not only acting as a radical scavenger and reducing power, but also peptide was a protecting membrane isolating lipid droplet against oxidation initiators.

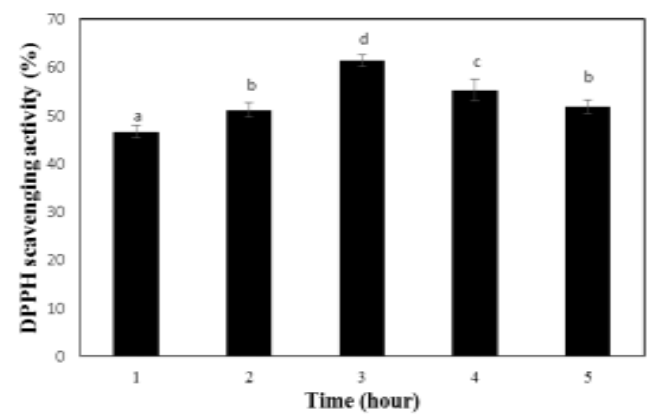

(a)

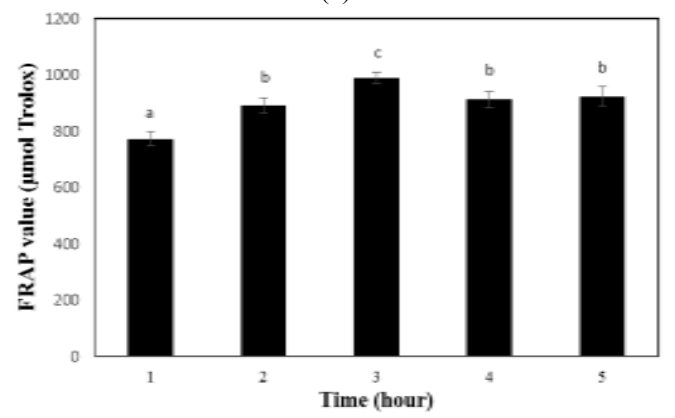

(b)

Figure 1. Effect of hydrolysis time on antioxidant activity of the proteolysate. Values represent the mean \pm SD of three determinations. Bars with different letters indicate significant differences $(\mathrm{P}<0.05)$. (a) using $\mathrm{DPPH} \bullet \mathrm{SM}$, (b) using FRAP method. 
DPPH• scavenging activity and FRAP value of the protein hydrolysates decreased as the hydrolysis time was greater than 3 hours $(\mathrm{P}<0.05)$ (Fig. 1). Another report also showed a decrease in $\mathrm{DPPH} \bullet \quad$ radical scavenging capacity of proteolysates with increasing proteolysis time [16]. The decrease in radical scavenging activity might be due to the generation of oxidant compounds, since Flavourzyme is aminopeptidase which may cut the active peptides into smaller sizes which have no antioxidant power, causing a decrease in antioxidant activity of hydrolysates.

In the study of Sara Bordbar et al. [17], FRAP values of stone fish tissue proteolysates also decreased after 5 hours of hydrolysis. Previous studies on ferric reducing antioxidant capacity of enzymatic proteolysates concluded that the reducing power was related to some factors including molecular weight of peptides, amino acid sequence of peptides, number of hydrophobic amino acids, and amount of sulphur containing and acidic amino acids. Besides, the presence of some amino acids such as Leu, Lys, Met, Tyr, Ile, His, and $\operatorname{Trp}$ has been reported contributing to the strong reducing power of proteolysates [17]. However, the mechanism of how the composition of peptides influenced their antioxidant capacity is needed to study more.

The highest DPPH• scavenging capacity of Flavourzyme proteolysate in this experiment reached $61.41 \%$ when the protein concentration of the proteolysate reached $7220 \mu \mathrm{g} / \mathrm{ml}$, and FRAP value reached $990 \mu \mathrm{M}$ Trolox equivalent after 3 hours of proteolysis. The great FRAP value indicated that hydrolysates could donor the electron to the free radical, leading to the prevention of oxidation propagation. After 3 hours of proteolysis, the rate reached the steady phase and the prolongation in hydrolysis had no significant effect on the radical scavenging power and reducing potential.

\subsection{Effect of enzyme/substrate ratio on antioxidant activity of proteolysate}

The relation between the enzyme/substrate ratio and the antioxidant activity of proteolysates measured by DPPH $\bullet$ radical scavenging assay and FRAP method were determined as illustrated in Fig. 2.

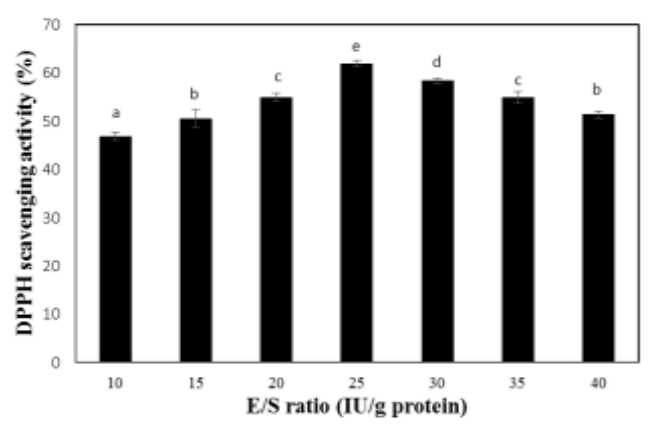

(a)

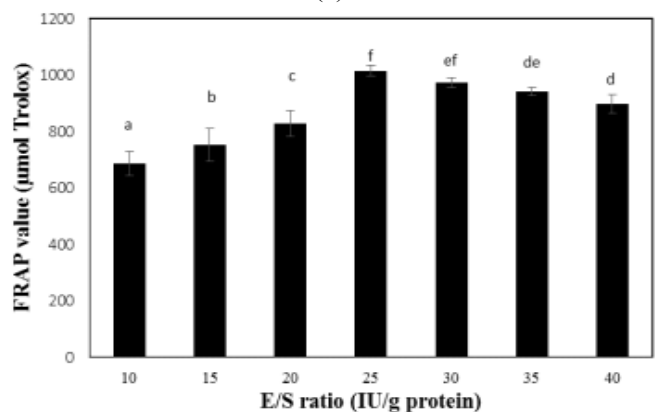

(b)

Figure 2. Effect of the E/S ratio on antioxidant activity of the proteolysate. Values represent the mean \pm SD of three determinations. Bars with different letters indicate significant differences $(\mathrm{P}<0.05)$. (a) using DPPH• SM, (b) using FRAP method.

From the result, enhancing the amount of Flavourzyme led to the increase in the antioxidant activity of proteolysate $(\mathrm{P}<0.05)$.

This indicated that peptide bonds were more extensively cleaved in the presence of a higher amount of enzyme or the peptides released were further hydrolyzed, producing amino acids and smaller peptides by the enzyme. It led to the change in the antioxidant activity. The DPPH radical scavenging activity and FRAP value of the hydrolysate significantly decreased $(\mathrm{P}<0.05)$ when the enzyme amount was exceeded (Fig. 2). Similar result was reported by S. Tanuja et al. (2014) [18] with proteolysate from $\mathrm{P}$. hypophthalmus frame meat. This may be due to the breakdown of antioxidant peptides formed during early stages of the hydrolysis process. In our research, with the $\mathrm{E} / \mathrm{S}$ ratio of $25 \mathrm{U} / \mathrm{g}$ protein, the highest DPPH scavenging potential of $61.94 \%$ and the highest FRAP value of $990.32 \mu \mathrm{M}$ Trolox equivalent were obtained.

3.4 Determination of degree of hydrolysis $(\mathrm{DH})$ of the proteolysate, IC50 and FRAP value of the peptide fractions and comparison with those of vitamin $C$ and $B H T$

The DH of Tra catfish by-product-derived 
proteolysate in this study reached $37.39 \%$ when $\mathrm{pH}$, temperature, $\mathrm{E} / \mathrm{S}$ ratio and hydrolysis time were $7,50{ }^{\circ} \mathrm{C}, 25 \mathrm{U} / \mathrm{g}$ protein, and 3 hours, respectively. The IC50 and FRAP value of the peptide fractions, vitamin $\mathrm{C}$ and BHT were presented in Table 1.

Table 1 . The IC50 and frap value of the peptide fractions, vitamin $\mathrm{C}$ and $\mathrm{BHT}$

\begin{tabular}{|c|c|c|c|c|c|}
\hline $\begin{array}{c}\text { Antioxidant } \\
\text { activity }\end{array}$ & $\begin{array}{l}\text { 10-30 } \\
\text { KDa }\end{array}$ & $\begin{array}{l}5-10 \\
\text { KDa }\end{array}$ & $\begin{array}{c}<5 \\
\text { KDa }\end{array}$ & BHT & $\begin{array}{c}\text { Vitamin } \\
\mathrm{C}\end{array}$ \\
\hline $\begin{array}{l}\text { IC50 } \\
(\mu \mathrm{g} / \mathrm{mL})\end{array}$ & $\begin{array}{l}5847.73 \\
\pm 128.68\end{array}$ & $\begin{array}{l}4709.3 \\
\pm 222.2\end{array}$ & $\begin{array}{l}3079.34 \\
\pm 75.29\end{array}$ & $\begin{array}{l}1034.29 \\
\pm 20.5\end{array}$ & $\begin{array}{l}10.68 \\
\pm 0.21\end{array}$ \\
\hline
\end{tabular}

$\begin{array}{llllll}\text { FRAP value } & 291.4 & 323.62 & 611.28 & 29483.28 & 46095.77\end{array}$ $(\mu \mathrm{M}$ Trolox $) \pm 2.65 \quad \pm 2.54 \quad \pm 4.5 \quad \pm 643.43 \quad \pm 403.38$

The result revealed that the $<5 \mathrm{KDa}$ peptide fraction showed highest antioxidant potential, followed by the 5-10KDa and 10-30KDa fractions. This finding is in agreement of those of ChangBum Ahn et al. [2], Jae-Young Je et al. [3], Ahmed Barkia et al. [4] who reported that lowermolecular-weight peptide showed higher antioxidant capacity. The IC50 of the $<5 \mathrm{KDa}$ peptide fraction was around $3.08 \pm 75.29 \mathrm{mg} / \mathrm{mL}$, which was 3 fold higher than that of BHT and 288 fold higher than that of vitamin $\mathrm{C}$ (Table 1). The FRAP value of the $<5 \mathrm{KDa}$ fraction reached 611.28 $\pm 4.5 \mu \mathrm{M}$ Trolox, which was 48 fold and 75 fold lower than those of BHT and vitamin C, respectively (Table 1). Although the antioxidant potential of the peptide fractions in our research were lower than those of BHT and vitamin C, they are still promising to be used in the pharmaceutical and food industries as natural alternative antioxidants.

\section{CONCLUSIONS.}

In this study, the Tra catfish by-products were used as protein sources for isolation of antioxidant peptide fractions. Though antioxidant capacity of these peptide fractions were lower than those of vitamin $\mathrm{C}$ and $\mathrm{BHT}$, they are still promising to be used in the food industry and neutraceuticals as natural alternative antioxidants. Further detailed studies on purification and amino acid sequencing of these peptide fractions as well as the different mechanisms of their antioxidant potential are needed.

\section{TÀI LIỆU THAM KHẢO}

[1] J.-Y. Je et al, "Purification and Antioxidant Properties of Bigeye Tuna (Thunnusobesus) Dark Muscle Peptide on Free Radical-Mediated Oxidative Systems", J Med Food, vol. 11, no. 4, pp. 629-637, 2008.

[2] C. -B. Ahn, J.-G. Kim, and J.-Y, "Je-Purification and antioxidant properties of octapeptide from salmon byproduct protein hydrolysate by gastrointestinal digestion", Food Chem, vol. 147, pp. 78-83, 2014.

[3] J.-Y. Je et al, "Purification and characterization of an antioxidant peptide obtained from tuna backbone protein by enzymatic hydrolysis", Process Biochemistry, vol. 42, no. 5, pp. 840-846, 2007.

[4] A. Barkia et al, "Antioxidant activities of Sardinelle heads and/or viscera protein hydrolysates prepared by enzymatic treatment", Journal of Food Biochemistry, vol. 34, pp.303-320, 2010 .

[5] V. Klompong et al, "Comparative study on antioxidative activity of yellow stripe trevally protein hydrolysate produced from Alcalase and Flavourzyme", International Journal of Food Science and Technology, vol. 43, no. 6, pp. 1019-1026, 2008.

[6] AOAC-Methods of Analysis, Association of Official Analytical Chemists, 15th ed. Washington, DC, 2000.

[7] N. Bhaskar, and N. S. Mahendrakar, "Protein hydrolysate from visceral waste proteins of Catla (Catla catla): Optimization of hydrolysis conditions for a commercial neutral protease”, Bioresource Technology vol. 99, no. 10, pp. 4105-4111, 2008.

[8] M.L. Anson, "The estimation of pepsin, trypsin, papain, and cathepsin with hemoglobin", J. Gen. Physiol., vol. 22, pp. 79-89, 1938.

[9] O.H. Lowry, N.J. Rosebrough, A.L. Farr, and R.J. Randall, "Protein Measurement with the Folin Phenol Reagen”, J. Biol. Chem, vol. 193, pp. 265-272, 1951.

[10] N. Hoyle, and J. H. Merrit, "Quality of fish protein hydrolysate from herring (Clupea harengus)", Journal of Food Science, vol. 59, no. 1, pp. 76-79, 1994.

[11] H. M., Chen, K.Muramoto, F.Yamauchi, K.Fujimoto, \& $\mathrm{K}$ Nokihara, "Antioxidative properties of histidinecontaining peptides designed from peptide fragments found in the digests of a soybean protein ", Journal of Agricultural and Food Chemistry, vol. 46, no. 1, pp. 4953, 1998.

[12] I. F. F.Benzie, J. J.Strain, "The ferric reducing ability of plasma (FRAP) as a measure of antioxidant power: the FRAP assay”, Anal. Biochem, vol.239, no. 1, pp. 70-76, 1996.

[13] M.A. Amiza, N. S. Ashikin, and A.L. Faazaz, "Optimization of enzymatic protein hydrolysis from silver catfish (Pangasius sp.) frame”, International Food Research Journal, vol. 18, no. 2, pp. 775-781, 2011.

[14] J.-I. Yang, H.-Y. Ho, Y.-J. Chu and C.-J. Chow, "Characteristic and antioxidant activity of retorted gelatin hydrolysates from cobia (Rachycentroncanadum) skin", Food Chemistry, vol. 110, no. 1, pp. 128-136, 2008.

[15] E. Mendis, N. Rajapakse, and S. K. Kim, "Antioxidant properties of a radical scavenging peptide purified from 
enzymatically prepared fish skin gelatin hydrolysate", $J$. Agric Food Chemistry, vol. 53, no. 3, pp. 581-587, 2005.

[16] K.-C. Hsu, "Purification of antioxidative peptides prepared from enzymatic hydrolysates of tuna dark muscle by-product", Food Chemistry, vol. 122, no. 1, pp. 42-48, 2010.

[17] S. Bordbar, A. Ebrahimpour, A. A. Hamid, M. Y. A. Manap, F. Anwar, N. Saari, "The Improvement of The Endogenous Antioxidant Property of Stone Fish (Actinopygalecanora) Tissue Using Enzymatic Proteolysis", BioMed Research International, vol. 2013, pp. 1-9, 2013.

[18] S. Tanuja et al, "Functional and antioxidative properties of fish protein hydrolysate (FPH) produced from the frame meat of striped catfish Pangasianodon", Indian J. Fish., vol. 61, no. 2, pp. 82-89, 2014.
Tam Dinh-Le Vo works for the division of Food Technology, Faculty of Chemical Engineering, Ho Chi Minh City University of Technology - Viet Nam National University Ho Chi Minh City, Vietnam (email: vdlt@hcmut.edu.vn)

Cuong Vi Tran is a student of the division of Food Technology, Faculty of Chemical Engineering, Ho Chi Minh City University of Technology - Viet Nam National University Ho Chi Minh City, Vietnam.

\title{
Khảo sát hoạt tính kháng oxy hoá của các phân đoạn peptide từ dịch thuỷ phân protein phụ phẩm chế biến cá Tra sử dụng chế phẩm Flavourzyme ${ }^{\circledR} 500 \mathrm{mg}$
}

\author{
Võ Đình Lệ Tâm, Trần Vĩ Cường
}

Tóm tắt — Trong nghiên cứu này, hoạt tính kháng oxy hoá của các phân đoạn peptide thu nhận từ dịch thuỷ phân phụ phẩm chế biến cá Tra sử dụng thiết bị ly tâm siêu lọc (MWCO) $5 \mathrm{KDa}, 10 \mathrm{KDa}$ và $30 \mathrm{KDa}$ được khảo sát. Trước tiên, thành phần hoá học của phụ phẩm cá Tra được phân tích. Kết quả cho thấy phụ phẩm cá Tra gồm có $58,5 \%$ ẩm, 33,9\% protein, $50,1 \%$ lipid, và $15,8 \%$ tro (tính theo trọng lượng chất khô). Tiếp theo, ảnh hưởng của hàm lượng enzyme, thời gian thuỷ phân lên hoạt tính kháng oxy hoá của dịch thuỷ phân cũng được khảo sát sử dụng phương pháp nhốt gốc tự do DPPH• (2,2-diphenyl-1picrylhydrazyl) và phương pháp khử sắt (III) FRAP. Flavourzyme ${ }^{\circledR} 500 \mathrm{MG}$ được sử dụng cho quá trình thủy phân. Kết quả cho thấy hoạt tính kháng oxy hoá của dịch thuỷ phân đạt cực đại ở khi thời gian thuỷ phân 3h, tỉ lệ enzyme/cơ chất $(\mathrm{E} / \mathrm{S}) 25 \mathrm{U} / \mathrm{g}$ protein, nhiệt độ $500 \mathrm{C}, \mathrm{pH} 7$, và mức độ thuỷ phân $(\mathrm{DH})$ của dịch thuỷ phân đạt $37,4 \%$. Tiếp theo dịch thuỷ phân được tách phân đoạn sử dụng cột lọc $5 \mathrm{KDa}, 10 \mathrm{KDa}$ và $30 \mathrm{KDa}$ và khảo sát hoạt tính kháng oxy hóa của từng phân đoạn. Kết quả cho thấy phân đoạn peptide $<5 \mathrm{KDa}$ có hoạt tính kháng oxy hoá cao nhất với khả năng nhốt $50 \%$ gốc tự do $\mathrm{DPPH} \bullet$ (IC50) đạt $3079,34 \pm 75,29 \mu \mathrm{g} / \mathrm{mL}$ và giá trị FRAP đạt $611,28 \pm 4,5 \mu \mathrm{M}$ Trolox. Phân đoạn peptide thể hiện hoạt tính kháng oxy hóa mạnh thứ hai là phân đoạn $5-10 \mathrm{KDa}$ với IC50 và giá trị FRAP đạt lần lượt là 4709,3 \pm $222,22 \mu \mathrm{g} / \mathrm{mL}$ và $323,62 \pm 2,54 \mu \mathrm{M}$ Trolox. Phân đoạn $10-30 \mathrm{KDa}$ thể hiện hoạt tính kháng oxy hoá yếu nhất với giá trị IC50 đạt $5847,73 \pm 128,68 \mu \mathrm{g} / \mathrm{mL}$ và giá trị FRAP đạt 291,4 $\pm 2,65 \mu \mathrm{M}$ Trolox. Các phân đoạn peptide có hoạt tính kháng oxy hoá thu nhận từ phụ phẩm chế biến cá Tra có tiềm năng sử dụng như những chất kháng oxy hóa tự nhiên trong công nghiệp thực phẩm và dược phẩm.

Tù khóa — hoạt tính kháng oxy hoá, peptide kháng oxy hoá, dịch thuỷ phân, phụ phẩm cá Tra. 